\title{
A new mathematical approximation for the current density of ionospheric plasma
}

\author{
Ali YEŞIL ${ }^{1} \mathscr{\&}$, Mustafa YENEROĞLU ${ }^{2}$

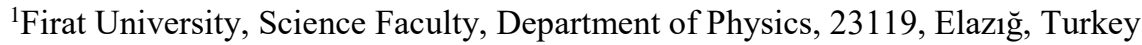 \\ ${ }^{2}$ Firat University, Science Faculty, Department of Mathematics, 23119, Elazı $\breve{g}$, Turkey \\ $\bowtie:$ ayesil@ firat.edu.tr
}

Received (Geliş):10.01.2017Ｒevision (Düzeltme):25.03.2017～Accepted (Kabul): 10.04.2017

\begin{abstract}
The current density depending upon conductivity and electric field in any medium is very important in any region of ionospheric plasma especially for an electromagnetic wave sending from Earth to ionosphere. Due to this, we build up new mathematical method for ionospheric current density and rendered diagonal case of the conductivity tensor possessing nine components in ionospheric plasma and the current density changes formed by conductivity has been shown mathematically. This method will precisely determine the direction of current and how much the magnitude of current resulting from conductivity will be able to create. Besides, this approximation will be created a good model for future work in ionospheric plasma, especially conductivity, diffusion and thermal conductivity.
\end{abstract}

Keywords: Current density, conductivity, ionospheric plasma

\section{Iyonosferik plazmanın akım yoğunluğu için yeni bir matematiksel yaklaşım}

\section{ÖZ}

Herhangi bir ortamda iletkenik ve elektrik alana bağlı olan akım yoğunluğu dünyadan iyonosfere gönderilen herhangi bir elektromanyetik dalga için iyonosferik plazmanın bir bölgesinde çok önemlidir. Bundan dolayı, biz ionosferik akım yoğunluğu için yeni bir matematiksel methot geliştirdik ve iyonosferik plazmada dokuz bileşene sahip olan iletkenlik tensörünü diagonal hale getirdik.Illetkenlik tarafından meydana gelen akım youğunlukları değişimleri matematiksel olarak gösterdik. Bu metot akım younluğunun yönünü ve iletkenlikten kaynaklanan akımın büyüklüğ̈̈nün nekadar olabileceğini kesin bir şekilde belirleyecektir. Bunun yanısıra, bu yaklaşım iyonosferik plazma çalışmaları için gelecekte iyi bir model olacaktır. Özellikle iletenklik, diffüzyon ve termal iletekenlik çalışmaları için.

Anahtar Kelimeler: Akım yoğunluğu, iletkenlik, İyonosferik plazma

\section{INTRODUCTION}

The characteristic of ionospheric plasma depend on electric fields, current density, conductivity and refractive index [1-3]. The refractive index is very important in ionospheric plasma because it related to reflection, propagation and refractive of electromagnetic waves and determines how much will be reflected and transmitted for an electromagnetic wave sending from Erath to ionosphere [4,5]. Due to this, the refractive index of any medium associated with directly the conductivity of any medium especially in ionospheric plasma. Numerous investigators have been studied about conductivities for both isotropic and anisotropic conditions as depending upon coordinate system in ionospheric plasma and have been made a big contribution to ionospheric plasma but the conductivities to have been obtained as a result of their work "possessing tensorial form" difficult to understand in which direction and how effective[1-12]. Due to these reasons, we have done a new approximation for current density and conductivities tensor in ionospheric plasma. We hope that this new approximation will facility be provided and will done more understandable to current density and the calculations of the refractive index in ionospheric plasma in future works.

The reconsideration of the conductivity tensor for cold plasma condition in ionospheric plasma

The force acting on electron in the cold plasma is given by

$\mathrm{m} \frac{\mathrm{d} \mathbf{V}}{\mathrm{dt}}=-\mathrm{e}[\mathbf{E}+\mathbf{V} \times \mathbf{B}]-\mathrm{mu} \mathbf{V}$ 
It is considered that the velocities and fields vary $\mathrm{e}^{(\mathbf{k} \cdot \mathbf{r}-\omega \mathrm{t})}$. In which, V: velocity of electrons, $\mathbf{E}$ : electric field, $\mathbf{B}$; Magnetic field and e, $\mathrm{m}$; charge and mass of electron, respectively. The current density is obtained as follows.

$$
\mathbf{J}=\sigma_{0} \mathbf{E}+\left(\frac{\omega_{c}}{\mathrm{~m}(\mathrm{v}-\mathrm{i} \omega)}\right)(\mathbf{J} \times \mathbf{a})
$$

Where $\quad \sigma_{0}=\frac{\mathrm{Ne}^{2}}{\mathrm{~m}(\mathrm{v}-\mathrm{i} \omega)} \quad$ is the longitudinal conductivity, $\omega_{\mathrm{c}}=\left|\frac{\mathrm{qB}}{\mathrm{m}}\right|$ is the gyro-frequency for electron, $\mathbf{B}=\mathrm{B}_{0} \mathbf{a}_{z}$ is magnetic field and $\mathbf{a}_{z}$ is the unit vector, $v_{e}=v_{e i}+v_{e n}$ is electron-ion and electronneutral collisions frequencies, $\mathrm{N}$ is the electron density and $\omega$ is wave frequency[1,7]. If the Eq.(3) is solved in the Cartesian coordinates system, according to ohm laws, the form of the conductivity is given by

\section{$\mathbf{J}=\sigma . \mathbf{E}$}

If the pressure-gradient term in eq.2 is neglected $(\nabla \mathrm{P}=0)$, the conductivity tensor known for cold plasma is obtained by[4].

$$
\sigma=\left[\begin{array}{ccc}
\sigma_{1} & -\sigma_{2} & 0 \\
\sigma_{2} & \sigma_{1} & 0 \\
0 & 0 & \sigma_{0}
\end{array}\right]
$$

After mathematical manipulation, the eigenvalues of the conductivity tensor are obtained by

$$
\lambda_{1}=\sigma_{0}, \lambda_{2}=\sigma_{1}-\mathrm{i} \sigma_{2} \text { and } \lambda_{3}=\sigma_{1}+\mathrm{i} \sigma_{2}
$$

From here eigenvectors with respect to these eigenvalues are composed as follow

$$
\alpha=\left[\begin{array}{l}
0 \\
0 \\
1
\end{array}\right] \beta=\frac{1}{\sqrt{2}}\left[\begin{array}{c}
-\mathrm{i} \\
1 \\
0
\end{array}\right] \text { and } \gamma=\frac{1}{\sqrt{2}}\left[\begin{array}{l}
\mathrm{i} \\
1 \\
0
\end{array}\right]
$$

The matrix and its inverse obtained eigenvector are follow as

$$
\mathrm{P}=\left[\begin{array}{ccc}
0 & -\frac{\mathrm{i}}{\sqrt{2}} & -\frac{\mathrm{i}}{\sqrt{2}} \\
0 & \frac{1}{\sqrt{2}} & \frac{1}{\sqrt{2}} \\
1 & 0 & 0
\end{array}\right] \text { and it's inverse }
$$$$
\mathrm{P}^{-1}=\left[\begin{array}{ccc}
0 & 0 & 1 \\
\frac{\mathrm{i}}{\sqrt{2}} & \frac{1}{\sqrt{2}} & 0 \\
-\frac{\mathrm{i}}{\sqrt{2}} & \frac{1}{\sqrt{2}} & 0
\end{array}\right]
$$

The diagonal matrix of the conductivity tensor is obtained by

$$
\begin{gathered}
\Lambda=\mathrm{P}^{-1} \mathrm{AP}=\left[\begin{array}{ccc}
\sigma_{0} & 0 & 0 \\
0 & \sigma_{1}-\mathrm{i} \sigma_{2} & 0 \\
0 & 0 & \sigma_{1}+\mathrm{i} \sigma_{2}
\end{array}\right] \\
\mathrm{P}^{-1} \mathbf{J}=\Lambda\left(\mathrm{P}^{-1} \mathbf{E}\right)
\end{gathered}
$$

According to the above equation, new expression for the current density is formed by

$$
\left[\begin{array}{c}
\mathbf{J}_{z} \\
\frac{\mathrm{i} \mathbf{J}_{\mathrm{x}}+\mathbf{J}_{\mathrm{y}}}{\sqrt{2}} \\
\frac{-\mathrm{i} \mathbf{J}_{\mathrm{x}}+\mathrm{J}_{\mathrm{y}}}{\sqrt{2}}
\end{array}\right]=\left[\begin{array}{ccc}
\sigma_{0} & 0 & 0 \\
0 & \sigma_{1}-\mathrm{i} \sigma_{2} & 0 \\
0 & 0 & \sigma_{1}+i \sigma_{2}
\end{array}\right]\left[\begin{array}{l}
\mathrm{E}_{\mathrm{z}} \\
\mathrm{E}_{\mathrm{y}} \\
\mathrm{E}_{\mathrm{x}}
\end{array}\right]
$$

From here, the current densities

$$
\begin{gathered}
J_{z}=\sigma_{0} E_{z} \\
\frac{i J_{x}+J_{y}}{\sqrt{2}}=\left(\sigma_{1}-i \sigma_{2}\right)\left[\frac{i E_{x}}{\sqrt{2}}+\frac{E_{y}}{\sqrt{2}}\right] \\
-\frac{i J_{x}+J_{y}}{\sqrt{2}}=\left(\sigma_{1}+i \sigma_{2}\right)\left[-\frac{i E_{x}}{\sqrt{2}}+\frac{E_{y}}{\sqrt{2}}\right]
\end{gathered}
$$

The current densities are obtained by 


$$
\left[\begin{array}{l}
\mathbf{J}_{\mathrm{x}} \\
\mathbf{J}_{\mathrm{y}} \\
\mathbf{J}_{\mathrm{z}}
\end{array}\right]=\left[\begin{array}{ccc}
\sigma_{1} & -\sigma_{2} & 0 \\
0 & \sigma_{1} & 0 \\
0 & 0 & \sigma_{0}
\end{array}\right]\left[\begin{array}{l}
\mathrm{E}_{\mathrm{x}} \\
\mathrm{E}_{\mathrm{y}} \\
\mathrm{E}_{\mathrm{z}}
\end{array}\right]
$$

When eq.(8) and eq.(5) are compared, The conductivity term affecting $\mathrm{Jz}$ is only longitudinal conductivity $\left(\sigma_{0}\right)$ for eq.(5) and eq.(8), but the conductivities affecting $\mathbf{J}_{\mathrm{x}}$, $\mathrm{J}_{\mathrm{y}}$ are $\sigma_{1}$ (Pedersen) and $\sigma_{2}$ (Hall conductivity) in eq.(5). This makes both Jx and Jy current difficult to interpret. Jy current in eq.(8) only depends on $\sigma_{1}$, but the interpretation of $J_{x}$ in eq.(8) is still difficult in ionospheric plasma. In future works, when the Earth's magnetic field is considered as three-dimensional, the conductivity tensor is very complex and we think that new approximation will be provided a big advantage not only electrical conductivity but also thermal conductivity and diffusion in the ionospheric plasma[17].

\section{CONCLUSION}

We have developed a new approach to the current density of ionospheric plasma after some mathematical manipulation. After the conductivity tensor "directiondependent" render diagonal matrix we have resolved the motion equation for the current density in ionospheric plasma. We hope that this approach could be used for direction-dependent studies such as diffusion and thermal conductivity in ionospheric plasma.

\section{REFERENCES}

[1] Aydogdu M., Ozcan O. Effect of magnetic declination on refractive index and wave polarization coefficients of electromagnetic wave in mid-latitude ionosphere, Indian Journal of Radio Space Science. 25, 263-70, 1996.

[2] Aydogdu M., Ozcan O. The possible effects of the magnetic declination on the wave polarization coefficients at the cutoff point. Progress in Electromagnetic Research, PIER 30, 179-190. Abstract Journal of Electromagnetic Waves and Applications. 14, 1289-1290, 2001.

[3] Aydoğdu M., Yeşil A., Güzel E. The group refractive indices of HF waves in the ionosphere and departure from the magnitude without collisions. Journal of Atmospheric and Solar-Terrestrial Physics. 66, 343-348, 2004.

[4] Bittencourt J. A. Fundamentals of plasma physics. Springer Science Business Media, 2013.

[5] Rishbeth H. Garriot O. K. Introduction to Ionospheric Physics, Academic Pres, New York, 175-186, 1969.

[6] Rishbeth H., Physics and Chemistry of The Ionospheric Contemp, Phys, 14, 229-240, 1973.

[7] Sagir S., Atici R., Ozcan O., Yüksel N. The effect of the stratospheric $\mathrm{QBO}$ on the neutral density of the $\mathrm{D}$ region. Ann. Geophys. 58, A0331-8, 2015.

[8] Sagir S., Karatay S., Atici R., Yesil A., Ozcan O, The relationship between the Quasi Biennial Oscillation and Sunspot Number. Advances in Space Research. 55, 106112, 2015.
[9] Sagir S., Yesil A., Sanac G., Unal I. The characterization of diffusion tensor for mid-latitude ionospheric plasma. Annals of Geophysics, 57, A0216-6, 2014.

[10] Yeşil A., Sağır S., Kurt K. The Behavior ofthe Classical Diffusion Tensor for Equatorial Ionospheric Plasma. Journal of Science, 13, 123-127, 2016.

[11] Kurt K., Yeşil A., Sağır S., Atıcı R. The Relationship of Stratospheric QBO with the Difference of Measured and Calculated NmF2. Acta Geophys. 64, 2781-2793, 2016.

[12] Yesil A., Sagir S., Ozcan O. Comparison of maximum electron density predicted by IRI-2001 with that measured over Chilton station. E-Journal of New World Sci. Acad. 4, 92-99, 2009. 
